\title{
Statistical analysis of clinopyroxenes from deep-sea basalts
}

\author{
Elaine L..Schweitzer, James J. Papike and A. Edward Bence \\ Department of Earth and Space Sciences, State University of New York \\ Stony Brook, New York 11794
}

\begin{abstract}
Pyroxene analyses of superior quality, from DsDP Legs $11,15,17,34$, and 37, have been used to identify the various basalt groups from pyroxene chemistry. Cluster analysis, factor analysis, and variation plots give insight into the crystal chemistry of the pyroxenes. The tholeiitic and alkalic pyroxene groups differ primarily in $\mathrm{Cr}_{2} \mathrm{O}_{3}$, TiO $\mathrm{Ti}_{2}$, and $\mathrm{Na}_{2} \mathrm{O}$ contents. Tholeitic pyroxenes are high in $\mathrm{Cr}_{2} \mathrm{O}_{3}$ and low in $\mathrm{Na}_{2} \mathrm{O}$ and $\mathrm{TiO}_{2}$, relative to an average pyroxene. For the same oxides, pyroxenes from alkalic basalts are high in $\mathrm{TiO}_{2}$ and $\mathrm{Na}_{2} \mathrm{O}$, and low in $\mathrm{Cr}_{2} \mathrm{O}_{3}$. Two pairs of cations, $\mathrm{Ti}^{\mathrm{IV}}{ }^{\mathrm{Al}} \mathrm{Al}$ and $\mathrm{Fe}^{3+}{ }^{\mathrm{IV}} \mathrm{Al}$, have high correlation coefficients in all of the groups. It appears that common substitutions which occur in deep-sea pyroxenes are: $\mathrm{Al}$ for $\mathrm{Si}$ in a tetrahedral site combined with $\mathrm{Ti}$ or $\mathrm{Fe}^{3+}$ substituting for $\mathrm{Mg}$ or $\mathrm{Fe}^{2+}$ (respectively) in the octahedral M1 site.
\end{abstract}

\section{Introduction}

Pyroxenes are important recorders of basalt petrogenesis. Detailed investigations of the crystal chemistry of mare basalt pyroxenes (Bence and Papike, 1972) in conjunction with experimental studies (Grove and Bence, 1977) reveal that the pyroxenes are recorders of bulk chemistry, $\mathrm{O}_{2}$, mineral paragenesis, and cooling rate. In ocean-ridge basalts, clinopyroxene follows olivine and plagioclase in the low-pressure crystallization sequence, and its chemistry reflects conditions of late-stage crystallization. However, at high pressures ( $~ 10$ kbar), clinopyroxene can be a liquidus phase (Kushiro, 1973; Bender et al., 1978), and its chemistry will reflect these conditions of crystallization.

We have studied pyroxenes from 8 drill sites of 5 DsDP legs, in order to get a broad view of deep-sea basalt pyroxene chemistry. Cluster and factor analyses were used to simplify the large data base (1583 pyroxene analyses). The major objectives are to use the pyroxene chemistry (1) to identify the various basalt groups and the parageneses within those groups, and (2) to define systematics for pyroxene crystal chemistry. Preliminary results have been published by Schweitzer et al. (1978).

\section{Geologic background}

The pyroxenes are from a variety of deep-sea basalt localities (Fig. 1). Basalts from four of the five legs are oceanic tholeiites (DsDP Legs 11, 15, 34, and 37). Alkalic basalts recovered from Leg 17 are also considered. Basalts from Legs 11,34 , and 37 appear to have erupted at spreading centers, while the alkalic basalts from Leg 17 are products of off-ridge volcanism. Leg 15 basalts may have been the product of flood-type volcanism (Donnelly, 1973), but this interpretation is disputed by Christofersson (1976). Basalts from these legs were chosen for statistical analysis for the following reasons: (1) to represent the two major oceanic basalt types, while maintaining, at least nominally, the relative abundance of the two types; (2) to use tholeiites which varied in age and/or physical characteristics; and (3) to eliminate interlaboratory analytical biases by using only data collected at Stony Brook.

The basalts range from extensively altered (Leg 11) to very fresh (Leg 37). Many of the extensively altered ones contain smectite and zeolites, and show replacement of olivine and plagioclase (Myers et al., 1975; Ayuso et al., 1976). Sites 100 and 105 of Leg 11 yielded the oldest basalts used in this study, approximately 130 m.y. old (Hollister et al., 1972). Sites 146, 151, and 153 of Leg 15 in the central Caribbean yielded Cretaceous tholeiites (Edgar et al., 1973). Although the Leg 15 samples are from a tectonic setting different from that of oceanic tholeiites, they have similar major and trace element chemistries (Bence et al., 1975). Basalts from Sites 319A and 321 (Leg 34) underlie sediments which are 15 and 40 m.y. old, 


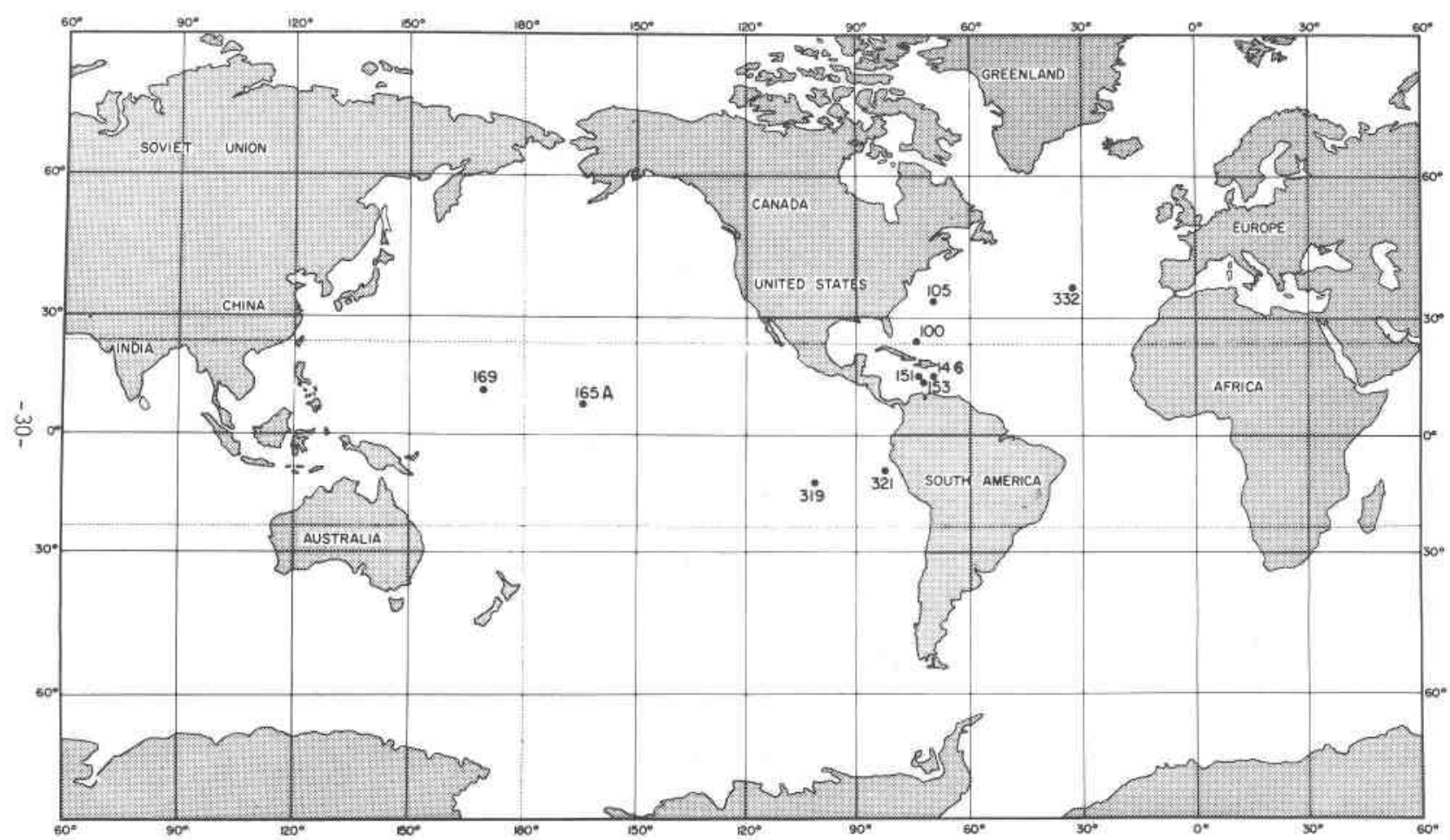

Fig. 1. Map showing the locations of the sites sampled.

respectively (Yeats et al., 1976). The youngest site sampled is Site 332 of Leg 37. The basalts from this site are approximately 3.5 m.y. old (Dmitriev, 1977), and some of the samples have been characterized as fresh, chemically primitive tholeiitic basalts (Hodges and Papike, 1977).

The alkalic basalts from Leg 17 are from two sites: $165 \mathrm{~A}$ and 169 . Site 169 also yielded tholeiitic rocks, but the pyroxene analyses used are only from the alkalic sill (Myers et al., 1975). These alkalic samples were selected because the pyroxenes are fresh and were analyzed in one electron microprobe laboratory.

\section{Methods}

\section{Data selection}

The pyroxene analyses were collected on an automated ARL EMX-SM microprobe. Analyses used in this paper represent individual point analyses taken in most cases on zoned crystals; they were selected to represent the maximum composition ranges for the pyroxenes for the specific rocks studied. Data reduction procedures, carried out on-line, are those of Bence and Albee (1968). Nine elements (Si, Al, Ti, $\mathrm{Cr}, \mathrm{Fe}, \mathrm{Mn}, \mathrm{Mg}, \mathrm{Ca}, \mathrm{Na}$ ) were analyzed. Each analysis also had ferric iron estimated by the method of
Papike et al. (1974). In order to be selected for statistical treatment, each analysis had to have an oxide sum $=100 \pm 2$ weight percent, and it had to pass all of the following tests: (1) the sum of $\mathrm{Si}+{ }^{\mathrm{IV}} \mathrm{Al}=2 \pm 0.02$ atoms/ 6 oxygens; (2) octahedral cations $\left(\mathrm{Mn}, \mathrm{Fe}^{2+}\right.$, $\mathrm{Fe}^{3+}, \mathrm{Mg}, \mathrm{Ti}, \mathrm{Cr},{ }^{\mathrm{VI}} \mathrm{Al}$ ) sum to greater than 0.98 ; (3) the M2 site occupancy equals $1.0 \pm 0.02$; and (4) the charge balance equation ${ }^{\mathrm{VI}} \mathrm{Al}+{ }^{\mathrm{VI}} \mathrm{Fe}^{3+}+{ }^{\mathrm{VI}} \mathrm{Cr}^{3+}+$ $2 \mathrm{Ti}^{4+}={ }^{\mathrm{IV}} \mathrm{Al}+{ }^{\mathrm{M} 2} \mathrm{Na}$ \} balances within 0.02 charge.

The number of cations per formula unit was used in the statistical programs because it gives more in sight into the crystal chemistry of the pyroxenes than does similar treatment of the oxides, and provides information equally suitable to discriminate among the basalt groups.

The statistical programs could handle no more than 800 analyses at a time; consequently, the original data set was cut to 750 analyses ( 150 for each leg). Exactly 150 analyses were selected from the data available for each leg by using the crystal-chemical criteria stated above and more stringent constraints on the cation sums. The sum of the tetrahedral cations must equal 2.000 , and the total cation sum deviates at most only slightly from $4.000(3.985<x<$ 4.010). 


\section{Statistical techniques}

Cluster and factor analysis are both multivariate statistical techniques which condense and simplify data. Cluster analysis calculates distances between points in $n$-space ( $n=$ number of variables $)$ and then forms clusters of points based on the distances between them. Factor analysis also considers cases plotted in n-space and simplifies the variables so that the cases can be described in a more economical manner by a smaller number of factor axes.

Each set of 150 analyses was clustered using Biomedical Computer Program P2M (Dixon, 1975). The cations ${ }^{\mathrm{IV}} \mathrm{Al}, \mathrm{Fe}^{2+}, \mathrm{Fe}^{3+}, \mathrm{Mg}, \mathrm{Mn}, \mathrm{Ti}, \mathrm{Cr}, \mathrm{Ca}, \mathrm{Na}$, and ${ }^{\mathrm{VI}} \mathrm{Al}$ were the variables, and each analysis in the set was compared with the other 149 analyses so that more similar ones were grouped together in the resulting histogram. After the cluster analysis was performed, each set was separated into recognizable groups based on the dendritic histogram of the computer output. The groups and their mean cation and oxide compositions were then used as "summaries" of the total data set studied.

A factor analysis program (BMDP4M; Dixon, 1975) was run for each set of 150 analyses, and also for each group which was recognized from the cluster analyses. The variables used for the factor analysis were the same cations as above, with the addition of Si. In addition to the factors determined by this analysis, correlation coefficients were calculated for every pair of cations.

A cautionary note is appropriate at this point. Multivariate analysis is a means of increasing perception of a complex system by compressing many variable dimensions into a few. The power of this statistic is that the reduction can be performed and checked by computer. However, one must be aware that some of the procedures are highly dependent upon pattern recognition techniques (Naney et al., 1976). Thus, the reader must be careful not to overinterpret the pyroxene groups presented in this paper. Different techniques and different data sets could produce different clusters. In fact, in a compositional continuum the cluster analysis might define "groups." Nevertheless, the approach is extremely useful in simplifying the data and in identifying chemical systematics that might be otherwise overlooked.

\section{Results}

The clustering procedure separates the data into 9 groups of unequal numbers of analyses. Analyses
Table 1. Site distribution for the cluster groups

\begin{tabular}{cl}
\hline Group $^{\text {a }}$ & Site (\# of analyses) \\
\hline $11-1$ & $100(87)$ \\
$11-2$ & $105(47)$ \\
& $100(3)$ \\
15 & $146(104)$ \\
& $152(24)$ \\
$17-1$ & $169(47)$ \\
$17-2$ & $165 \mathrm{~A}(31)$ \\
$17-3$ & $165 \mathrm{~A}(50)$ \\
$34-1$ & $169(16)$ \\
& $319(64)$ \\
$34-2$ & $321(27)$ \\
$37-332$ & $321(15)$ \\
& $319(10)$ \\
\hline
\end{tabular}

${ }^{a}$ Groups are labelled as leg number-group number.

from Legs 11 and 34 formed 2 groups each, those from Leg 17 formed 3 groups, and those from Legs 15 and 37 formed one group each (Site 332 is the only site analyzed for Leg 37). The nine groups, broken down by site and the number of analyses from each site, are shown in Table 1. The cluster groups are identified by leg number and group number (i.e., Leg 17 , group 1 is 17-1). Analyses which did not fall into an identifiable group were not used in the group averages. The actual number of analyses in each group is listed in Table 1.

The mean oxide and cation compositions for each pyroxene group are shown in Table 2. As with the whole-rock compositions, the $\mathrm{Na}_{2} \mathrm{O}$ contents of the pyroxenes from alkalic basalts differ significantly from corresponding values for the tholeiites, but, for the other oxides, there is more variation within the three cluster groups of the alkalic basalts than between cluster groups for the alkalic and tholeiitic basalts. The cluster groups 17-1, 17-2, and 17-3 are from the alkalic basalts, and the 6 remaining cluster groups are from tholeiitic basalts.

Average "alkalic" and "tholeiitic" pyroxenes (Fig. 2a) were calculated using the mean oxide values from the alkalic and tholeiitic cluster groups. These two average pyroxene compositions were combined with the mean compositions of the 9 cluster groups in calculating the average pyroxene composition in the 

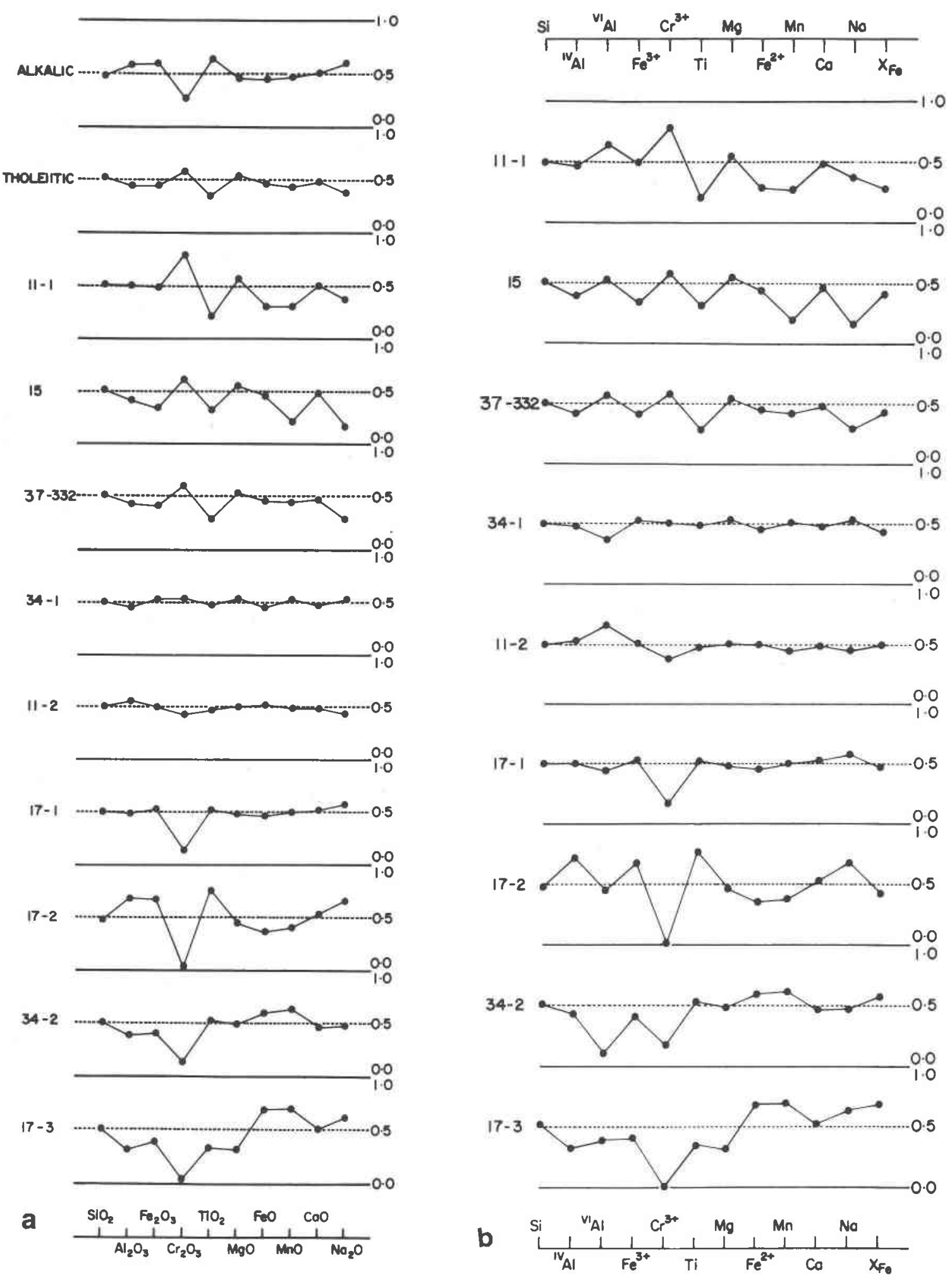

Fig. 2. (a) Oxide variations of pyroxene group averages, normalized to the average pyroxene of Table 2 . See text for details of the normalization procedure. (b) Cation variations of pyroxene group averages, normalized to the average pyroxene of $\mathrm{Table}^{2} X_{\mathrm{Fe}}=\mathrm{Fe}^{2+} /$ $\left(\mathrm{Fe}^{2+}+\mathrm{Mg}\right)$. See text for details of the normalization procedure. 
Table 2. Mean pyroxene cluster group compositions

\begin{tabular}{|c|c|c|c|c|c|c|c|c|c|c|}
\hline & $11-1$ & $11-2$ & 15 & $17-1$ & $17-2$ & $17-3$ & $34-1$ & $34-2$ & $37-332$ & Avg. Pyx. \\
\hline $\mathrm{SiO}_{2}$ & 51.32 & 48.95 & 51.50 & 49.29 & 43.94 & 48.56 & 50.26 & 49.55 & 51.21 & 49.36 \\
\hline $\mathrm{Al}_{2} \mathrm{O}_{3}$ & 3.93 & 4.81 & 2.75 & 3.75 & 8.24 & 1.80 & 3.30 & 2.47 & 3.10 & 3.86 \\
\hline $\mathrm{TiO}_{2}$ & 0.34 & 1.19 & 0.62 & 1.50 & 4.24 & 0.69 & 1.25 & 1.40 & 0.54 & 1.36 \\
\hline $\mathrm{Cr}_{2} \mathrm{O}_{3}$ & 0.63 & 0.12 & 0.25 & 0.02 & 0.00 & 0.01 & 0.18 & 0.02 & 0.23 & 0.16 \\
\hline $\mathrm{FeO}$ & 4.29 & 10.13 & 8.49 & 8.76 & 5.68 & 20.85 & 8.41 & 14.87 & 8.54 & 9.71 \\
\hline " $\mathrm{Fe}_{2} \mathrm{O}_{3}$ " & 1.87 & 1.95 & 0.98 & 2.16 & 4.05 & 1.26 & 2.08 & 1.33 & 1.41 & 1.96 \\
\hline $\mathrm{MnO}$ & 0.11 & 0.23 & 0.07 & 0.24 & 0.16 & 0.55 & 0.26 & 0.41 & 0.20 & 0.24 \\
\hline $\mathrm{MgO}$ & 17.97 & 14.01 & 16.81 & 13.21 & 11.65 & 6.04 & 15.52 & 13.21 & 16.24 & 13.98 \\
\hline $\mathrm{CaO}$ & 19.19 & 18.29 & 18.20 & 20.62 & 21.66 & 19.54 & 18.60 & 16.32 & 18.40 & 19.03 \\
\hline $\mathrm{Na}_{2} \mathrm{O}$ & 0.14 & 0.18 & 0.05 & 0.30 & 0.44 & 0.36 & 0.25 & 0.21 & 0.10 & 0.23 \\
\hline$\Sigma$ & 99.79 & 99.86 & 99.72 & 99.85 & 100.06 & 99.66 & 100.11 & 99.79 & 99.97 & 99.89 \\
\hline $\mathrm{Si}$ & 1.876 & 1.840 & 1.908 & 1.854 & 1.655 & 1.931 & 1.869 & 1.891 & 1.898 & 1.858 \\
\hline${ }^{\text {Iv }} \mathrm{Al}$ & 0.124 & 0.163 & 0.092 & 0.145 & 0.345 & 0.067 & 0.130 & 0.107 & 0.102 & 0.142 \\
\hline$\Sigma_{\text {tetrahedral }}$ & 2.000 & 2.003 & 2.000 & 1.999 & 2.000 & 1.998 & 1.999 & 1.998 & 2.000 & 2.000 \\
\hline $\mathrm{Ti}$ & 0.009 & 0.034 & 0.017 & 0.042 & 0.120 & 0.020 & 0.035 & 0.040 & 0.015 & 0.037 \\
\hline${ }^{{ }^{v} 1} \mathrm{Al}$ & 0.046 & 0.050 & 0.028 & 0.021 & 0.021 & 0.016 & 0.015 & 0.003 & 0.033 & 0.026 \\
\hline $\mathrm{Cr}$ & 0.018 & 0.003 & 0.007 & 0.001 & 0.000 & 0.000 & 0.005 & 0.001 & 0.007 & 0.005 \\
\hline " $\mathrm{Fe}^{3+"}$ & 0.051 & 0.055 & 0.027 & 0.061 & 0.115 & 0.038 & 0.058 & 0.038 & 0.039 & 0.053 \\
\hline $\mathrm{Fe}^{2+}$ & 0.131 & 0.318 & 0.265 & 0.276 & 0.179 & 0.695 & 0.262 & 0.475 & 0.271 & 0.319 \\
\hline $\mathrm{Mn}$ & 0.003 & 0.007 & 0.002 & 0.008 & 0.005 & 0.019 & 0.008 & 0.013 & 0.006 & 0.008 \\
\hline $\mathrm{Mg}$ & 0.979 & 0.783 & 0.927 & 0.740 & 0.654 & 0.355 & 0.860 & 0.751 & 0.892 & 0.771 \\
\hline$\Sigma_{\text {octahedral }}$ & 1.237 & 1.250 & 1.273 & 1.149 & 1.094 & 1.143 & 1.243 & 1.321 & 1.263 & 1.219 \\
\hline $\mathrm{Ca}$ & 0.752 & 0.736 & 0.722 & 0.831 & 0.874 & 0.833 & 0.741 & 0.667 & 0.729 & 0.765 \\
\hline $\mathrm{Na}$ & 0.010 & 0.013 & 0.003 & 0.022 & 0.032 & 0.028 & 0.018 & 0.015 & 0.007 & 0.016 \\
\hline$\Sigma_{\text {total cations }}$ & 3.999 & 4.002 & 3.998 & 4.001 & 4.000 & 4.002 & 4.000 & 4.001 & 3.999 & 4.000 \\
\hline
\end{tabular}

Note: Ferric iron was calculated for each analysis by the method of Papike et al. (1974). Groups 17-1, 17-2, and 17-3 are from alkalic basalts, all other groups are from tholeiitic basalts. Avg. Pyx. is an average pyroxene calculated using the mean compositions from the cluster groups, see text for details.

column labelled "Avg. Pyx." in Table 2. However, the mean cation composition in the Avg. Pyx. column was calculated using only the mean cation values from the 9 cluster groups.

The average whole-rock analyses listed in Table 3 indicate by the low sums, relatively high $\mathrm{K}_{2} \mathrm{O}$ and high $\mathrm{Fe}_{2} \mathrm{O}_{3}$ (where analyzed), that alteration has occurred. A major objective of this study is to attempt to see through the alteration of the whole rocks by chemically characterizing the essentially pristine pyroxenes. The whole-rock compositions listed in Table 3 are arranged to correspond to the 9 pyroxene cluster groups. Whole-rock analyses for sites and intervals corresponding to those of the pyroxene cluster groups were taken from the literature and averaged together so that they would correspond to the average pyroxene compositions of the cluster groups. The whole-rock alkalic basalt compositions ("cluster" groups $17-1,2,3$ ) are high in $\mathrm{TiO}_{2}, \mathrm{Na}_{2} \mathrm{O}$, and $\mathrm{K}_{2} \mathrm{O}$ relative to the tholeiites. In the pyroxene groups, only $\mathrm{Na}_{2} \mathrm{O}$ is consistently higher in the pyroxenes from alkalic basalts.

\section{Chemical characteristics}

The differences among the pyroxene cluster groups are easily observed on variation diagrams (Fig. 2a,b). The 9 cluster groups are arranged in Figure 2 so that similar patterns are in close proximity. The oxides or cations are ordered so that the ionic radii of the cations increase from left to right. The actual numerical values are derived from the ratios oxide/(oxide + average) and cation/(cation + average), where "oxide" and "cation" are the group mean values (Table 2) and "average" is the value for Avg. Pyx. (Table 2). The ratios are normalized so that Avg. Pyx. plots on the 0.5 line. If any oxide or cation value is higher than that of Avg. Pyx. it plots above the 0.5 line, and if it is lower it plots below the line. The resulting variation diagrams show differences and serve, like chondrite-normalized REE and transitionmetal plots, to distinguish the basalt groups. Two of the groups, 34-1 and 11-2, have mean compositions that are very similar to the mean of the whole data set; consequently, their patterns appear relatively flat. 
Table 3. Whole rock average compositions

\begin{tabular}{|c|c|c|c|c|c|c|c|c|c|}
\hline & $11-1$ & $11-2$ & 15 & $17-1$ & $17-2$ & $17-3$ & $34-1$ & $34-2$ & $37-332$ \\
\hline $\mathrm{SiO}_{2}$ & 49.7 & 49.0 & 50.4 & 44.26 & 42.04 & 46.49 & 50.2 & 49.9 & 48.46 \\
\hline $\mathrm{Al}_{2} \mathrm{O}_{3}$ & 16.4 & 15.3 & 15.4 & 14.31 & 13.61 & 15.01 & 14.40 & 13.9 & 17.95 \\
\hline $\mathrm{TiO}_{2}$ & 0.87 & 1.05 & 0.92 & 2.95 & 4.89 & 1.02 & 1.88 & 2.19 & 0.74 \\
\hline $\mathrm{Cr}_{2} \mathrm{O}_{3}$ & 0.03 & 0.06 & 0.00 & n.a. & n.a. & n.a. & 0.02 & 0.02 & 0.03 \\
\hline $\mathrm{FeO}$ & 8.78 & 9.70 & 9.93 & 7.54 & 7.72 & 7.37 & 11.2 & 12.2 & 3.15 \\
\hline $\mathrm{Fe}_{2} \mathrm{O}_{3}$ & n.a. & n.a. & n.a. & 4.75 & 5.26 & 4.25 & n.a. & n.a. & 3.86 \\
\hline $\mathrm{MnO}$ & 0.13 & 0.19 & 0.05 & 0.22 & 0.24 & 0.19 & 0.16 & 0.19 & 0.12 \\
\hline $\mathrm{MgO}$ & 8.51 & 7.83 & 8.67 & 6.86 & 6.22 & 7.50 & 7.03 & 6.60 & 7.05 \\
\hline $\mathrm{CaO}$ & 12.4 & 13.6 & 12.4 & 9.88 & 8.57 & 11.20 & 11.3 & 10.8 & 14.18 \\
\hline $\mathrm{Na}_{2} \mathrm{O}$ & 2.42 & 2.18 & 2.38 & 3.67 & 4.04 & 3.30 & 2.79 & 2.70 & 2.02 \\
\hline $\mathrm{K}_{2} \mathrm{O}$ & 0.11 & 0.29 & 0.04 & 1.25 & 2.12 & 0.39 & 0.31 & 0.24 & 0.18 \\
\hline$\Sigma$ & 99.24 & 99.20 & 100.19 & 95.69 & 94.71 & 96.72 & 99.29 & 98.74 & 97.74 \\
\hline
\end{tabular}

n.a. = not analyzed.

Data are averaged for the sites and combined into the groups:

11-1 Site 100 (Ayuso et al., 1976); electron microprobe.

11-2 Site 105 (Ayuso et al., 1976); electron microprobe.

15 Site 146 (Bence et al., 1975); electron microprobe.

17-1 Sites 165A and 169 (Bass et al., 1973); XRF and wet chemical.

17-2 Site 165A (Bass et al., 1973); XRF and wet chemical.

17-3 Site 169 (Bass et al., 1973); XRF and wet chemical.

34-1 Site 319 (Mazzullo and Bence, 1976); electron microprobe.

34-2 Sites 319 and 321 (Mazzullo and Bence, 1976); electron microprobe.

37-332 Sites 332A and 332B (Blanchard et al., 1976); XRF and wet chemical.

The behavior of $\mathrm{Cr}_{2} \mathrm{O}_{3}$ changes progressively from the top group to the bottom group in Figure $2 \mathrm{a}$; i.e., $\mathrm{Cr}_{2} \mathrm{O}_{3}$ is high relative to "average pyroxene" in the top group and low in the bottom groups.

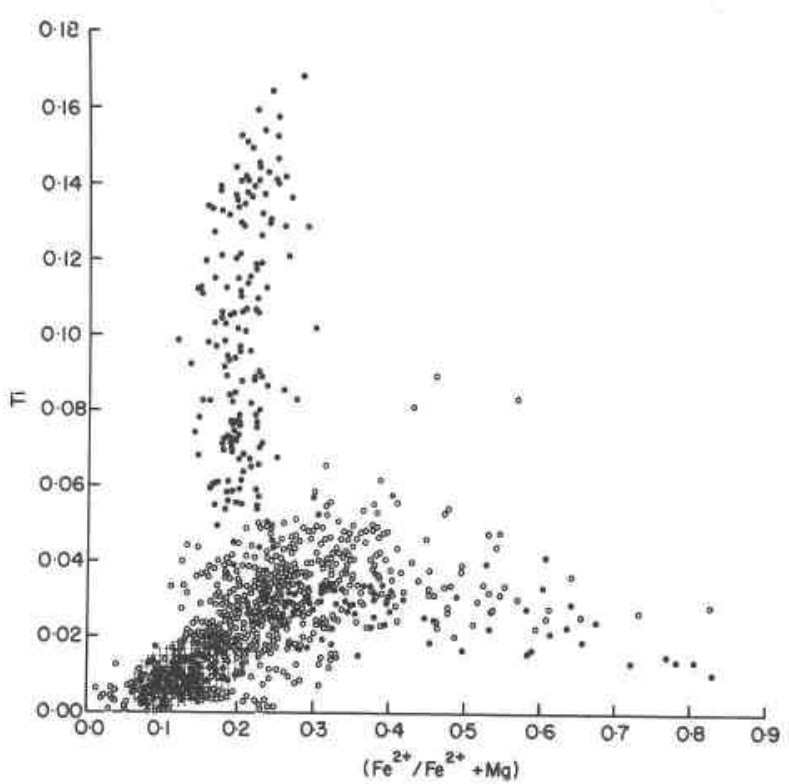

Fig. 3. $\mathrm{Ti}$ vs. $\mathrm{Fe}^{2+} /\left(\mathrm{Fe}^{2+}+\mathrm{Mg}\right.$ ) (atomic). The three groups plotted are: closed circles $=$ alkalic basalt pyroxenes, open circles $=$ tholeiitic basalt pyroxenes, closed triangles (in shaded region) $=$ pyroxenes from basalts collected at Site 100 of Leg 11. Units are cations per formula unit.
The average compositions of pyroxenes from alkalic and tholeiitic basalts, grouped separately, are shown at the top of Figure $2 \mathrm{a}$ and reflect clearly the chemical differences between the two basalt types. The major differences between tholeitic and alkalic basalts, as reflected in the pyroxene chemistry, are

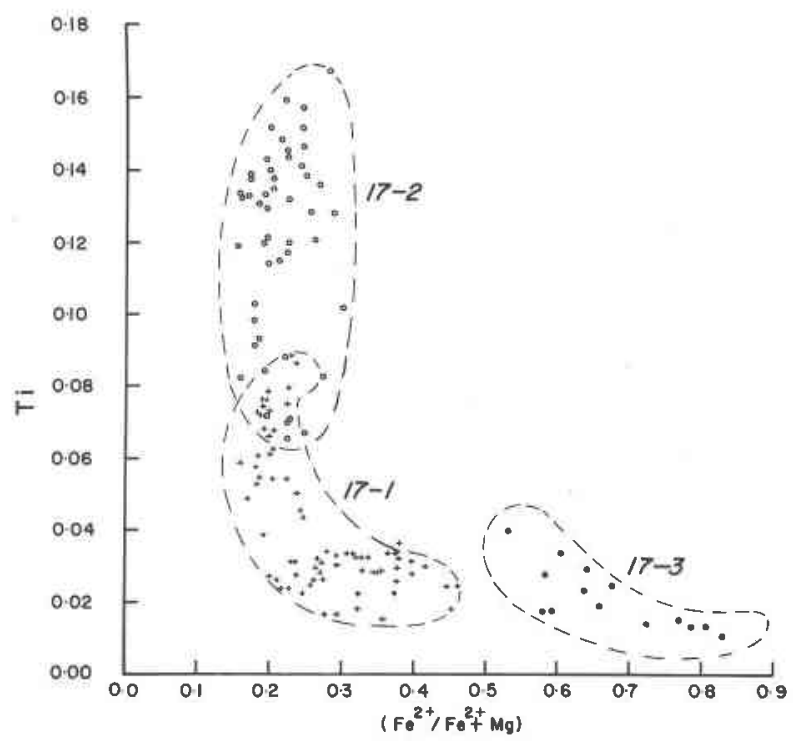

Fig. 3a. Ti vs. $\mathrm{Fe}^{2+} /\left(\mathrm{Fe}^{2+}+\mathrm{Mg}\right)$ (atomic). Three cluster groups for pyroxenes from alkalic basalts. Ti units are atoms per formula unit. 


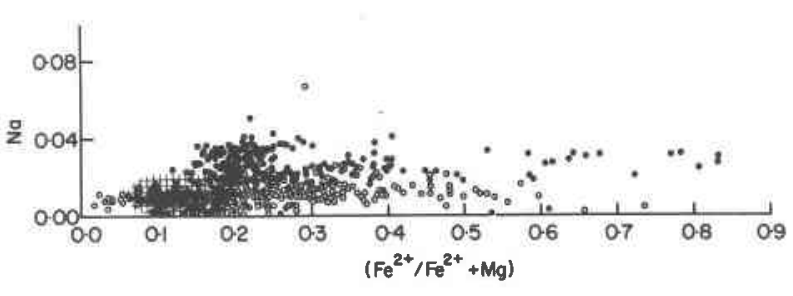

Fig. 4. $\mathrm{Na}$ us. $\mathrm{Fe}^{2+} /\left(\mathrm{Fe}^{2+}+\mathrm{Mg}\right.$ ) (atomic). Symbols for groups and units are as in Fig. 3.

best seen in the components other than $\mathrm{CaSiO}_{3}$ $\mathrm{MgSiO}_{3}-\mathrm{FeSiO}_{3}$. The pyroxenes from alkalic rocks are relatively low and those from tholeiites are relatively high in $\mathrm{Cr}_{2} \mathrm{O}_{3}$. Alkalic basalt pyroxenes are high in $\mathrm{TiO}_{2}$ and $\mathrm{Na}_{2} \mathrm{O}$. To a lesser degree $\mathrm{Al}_{2} \mathrm{O}_{3}$ and $\mathrm{Fe}_{2} \mathrm{O}_{3}$ are low in tholeiitic basalt pyroxenes and high in those from alkali basalts. The patterns for groups 11-1 and 15 closely follow the pattern of the tholeiitic group. Group 17-3 is very different from both the tholeiitic groups and the other two alkalic groups. Among the tholeiitic groups, 34-2 is unique.

Groups 34-2 (tholeiitic) and 17-3 (alkalic) do not appear to follow the patterns of the other groups of their types. For example, the $\mathrm{Fe}^{2+} /\left(\mathrm{Fe}^{2+}+\mathrm{Mg}\right)$ values for these two groups are higher than the average pyroxene value, and are higher than the $\mathrm{Fe}^{2+} /\left(\mathrm{Fe}^{2+}+\right.$ $\mathrm{Mg}$ ) value in any other group. Also, the overall appearance of the patterns for 34-2 and 17-3 are more similar to each other than they are to the other groups. Both of these pyroxene groups are from highly fractionated basalts, and this fact probably accounts for their similar patterns.

On a series of plots with various cations plotted against the atomic ratio $\mathrm{Fe}^{2+} /\left(\mathrm{Fe}^{2+}+\mathrm{Mg}\right)=X_{\mathrm{Fe}}$ (Figs. 3-10) we observe two features: (1) the characteristics of the two major basalt types (tholeiitic and alkalic); and (2) an indication of the crystal-chemical

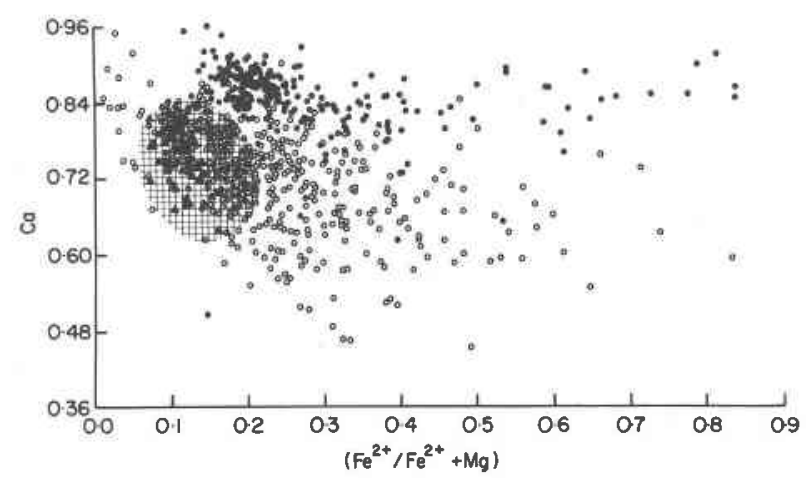

Fig. 5. Ca vs. $\mathrm{Fe}^{2+} /\left(\mathrm{Fe}^{2+}+\mathrm{Mg}\right.$ ) (atomic). Symbols for groups and units are as in Fig. 3.

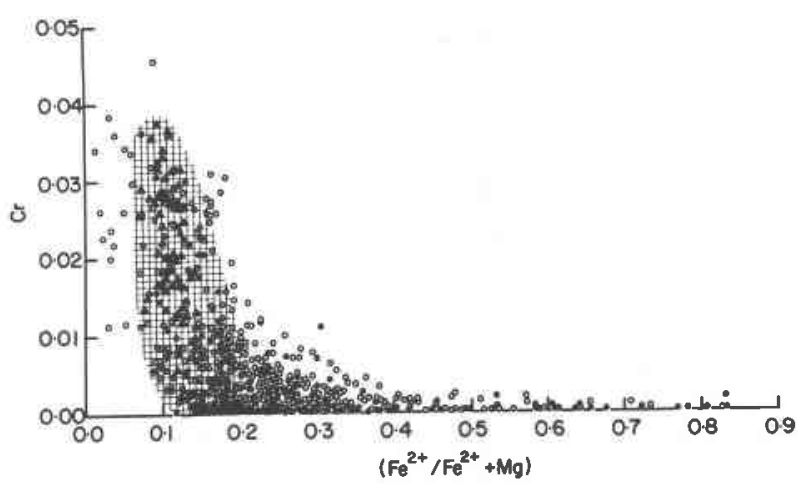

Fig. 6. $\mathrm{Cr}$ os. $\mathrm{Fe}^{2+} /\left(\mathrm{Fe}^{2+}+\mathrm{Mg}\right.$ ) (atomic). Symbols for groups and units are as in Fig. 3.

behavior of the various cations. For simplicity we distinguish only three groups of pyroxenes on the plot, namely those collected from alkalic basalts, those from tholeiitic basalts (exclusive of cluster group 11-1), and those from Site 100 of Leg 11. The pyroxenes from the Site 100 basalts constitute all of cluster group 11-1. It is significantly different from the other tholeiitic pyroxene cluster groups, consisting largely of analyses of xenocrysts and/or phenocrysts.

With the large numbers of analyses used, characteristics of the two basalt types are readily observed. Pyroxenes from alkalic basalts have a wide range of Ti concentrations with high values at low $X_{\mathrm{Fe}}$ and low values at high $X_{\mathrm{Fe}}$ (Fig. 3). In contrast Ti is positively correlated with $X_{\mathrm{Fe}}$ in tholeiitic basalt pyroxenes. Pyroxenes from Site 100 basalts are very low in $\mathrm{Ti}$ and very low in $X_{\mathrm{Fe}}$.

The trend of the alkalic basalt pyroxenes (Fig. 3) can be explained with the help of Figure 3a. This

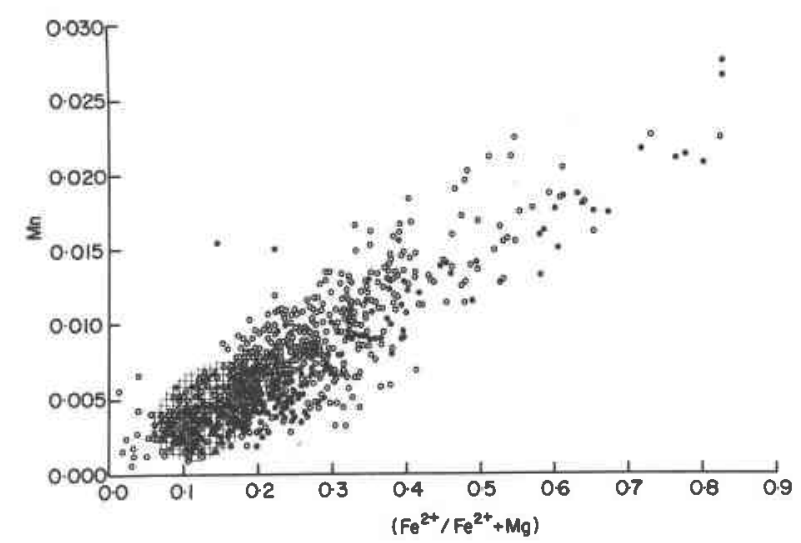

Fig. 7. $\mathrm{Mn}$ us. $\mathrm{Fe}^{2+} /\left(\mathrm{Fe}^{2+}+\mathrm{Mg}\right.$ ) (atomic). Symbols for groups and units are as in Fig. 3. 


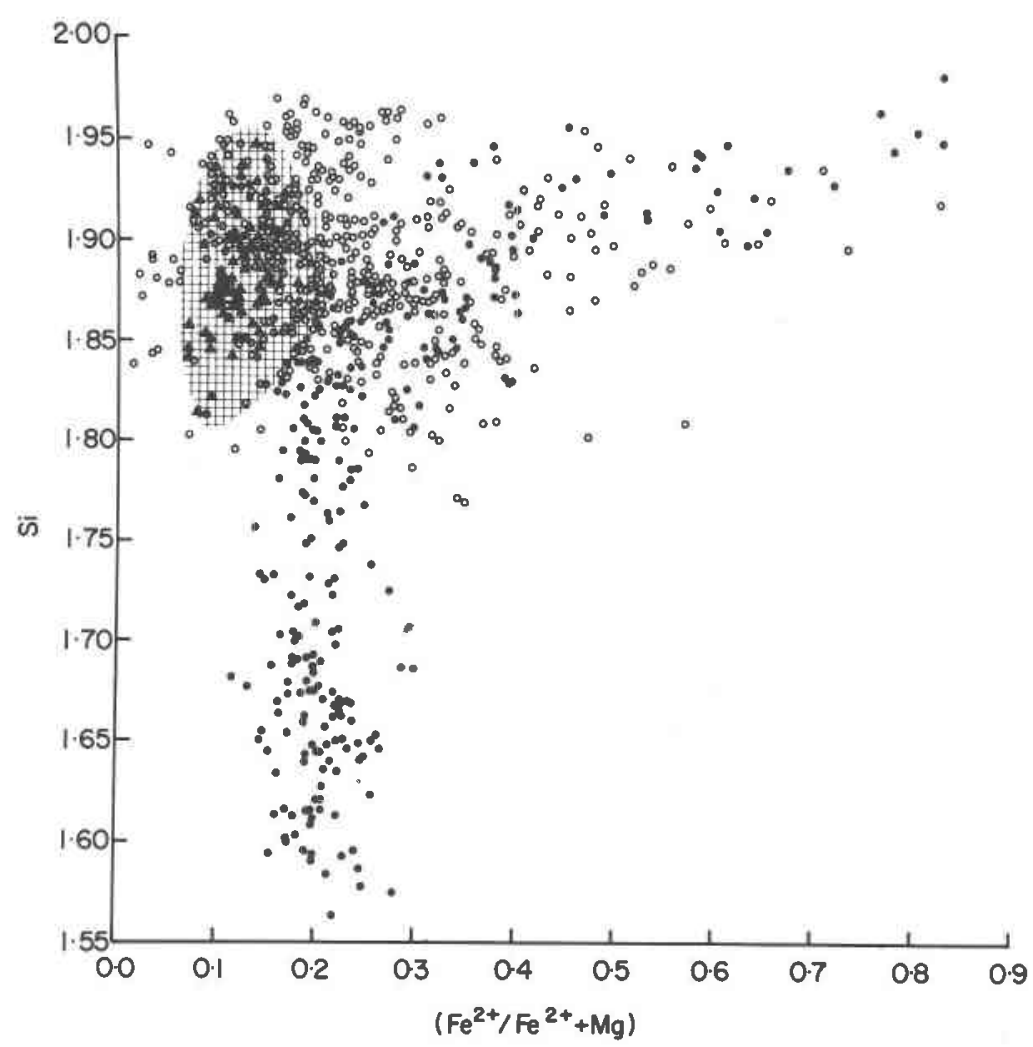

Fig. 8. Si vs. $\mathrm{Fe}^{2+} /\left(\mathrm{Fe}^{2+}+\mathrm{Mg}\right)$ (atomic). Symbols for groups and units are as in Fig. 3 .

figure is the same as Figure 3 except that it shows only the 3 alkalic cluster groups, 17-1, 17-2, and 17-3. These 3 groups represent 2 alkalic basalt drilling sites, and as shown in Table 1, groups 17-2 and 17-3 each represent only one site (165A and 169 , respectively) while group 17-1 consists of analyses from both sites.

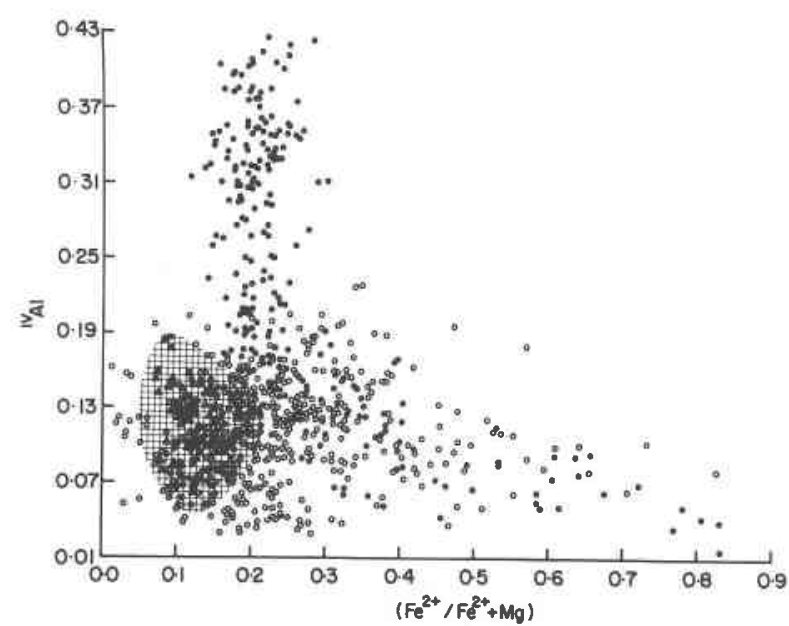

Fig. 9. ${ }^{\mathrm{IV}} \mathrm{Al}$ vs. $\mathrm{Fe}^{2+} /\left(\mathrm{Fe}^{2+}+\mathrm{Mg}\right.$ ) (atomic). Symbols for groups and units are as in Fig. 3.
The pyroxenes of groups 17-2 and 17-3 differ in $\mathrm{Ti}$ content, those of 17-2 being relatively high in $\mathrm{Ti}$ and low in $X_{\mathrm{Fe}}$, and those of 17-3 being low in Ti and relatively high in $X_{\mathrm{Fe}}$ (Fig. 3a). Therefore, groups 172 and $17-3$, reflecting the two sites, form 2 separate curves which appear as branches of the single alkalic pyroxene curve in Figure 3. Group 17-1 falls in the middle, where the slope of the curve in Figure 3 changes, at a $\mathrm{Ti}$ content of approximately 0.04 cations, which is where the two groups of Figure 3a meet. The difference in Ti content of the groups reflects the difference in bulk chemistry of the host basalts (Table 3 ).

The sodium contents of all the pyroxenes are rather low (Fig. 4), but a difference is noticeable between pyroxenes of alkalic basalts and those of tholeiitic basalts. Those from alkalic basalts are generally richer in $\mathrm{Na}$ than those from tholeiites. Pyroxenes from alkalic basalts are also slightly richer in calcium than pyroxenes from tholeiitic basalts (Fig. 5). Sodium and calcium contents are essentially independent of $X_{\mathrm{Fe}}$.

Tholeiitic basalt pyroxenes show an inverse relation between $\mathrm{Cr}$ and $X_{\mathrm{Fe}}$ (Fig. 6). Pyroxenes from all tholeiitic basalts which appear to be phenocrysts/ 
xenocrysts are characterized by high $\mathrm{Cr}$ and very low $X_{\mathrm{Fe}}$ (Fig. 6). Groundmass pyroxenes from these same sites are low in $\mathrm{Cr}$ and tend to have high $X_{\mathrm{Fe}}$. The alkalic basalt pyroxenes are low in $\mathrm{Cr}$.

The pyroxenes of all three plotted groups show a strong positive correlation between $\mathrm{Mn}$ content and $X_{\mathrm{Fe}}$ (Fig. 7). This trend is consistent with the common assumption that $\mathrm{Mn}$ behaves similarly to $\mathrm{Fe}^{2+}$ in pyroxenes.

Figures 8 and 9 give some insight into the crystal chemistry of tetrahedral sites in clinopyroxenes. A value of $2.00 \mathrm{Si}$ (Fig. 8) would indicate that the tetrahedral sites are completely filled by silicon. In the alkalic basalt pyroxenes $\mathrm{Si}$ commonly falls well below the value of 2.00 , with the deficiency compensated by ${ }^{\mathrm{IV}} \mathrm{Al}$ (Fig. 9). As $X_{\mathrm{Fe}}$ increases in alkalic basalt pyroxenes, $\mathrm{Si}$ also increases and ${ }^{\mathrm{IV}} \mathrm{Al}$ decreases. The distributions of the three cluster groups representing alkalic basalts in Figures 8 and 9 are similar to their distributions in Figure 3, with groups 17-2 and 17-3 forming the low and high $X_{\mathrm{Fe}}$ branches, respectively. In contrast to the behavior of pyroxenes from alkalic basalts, those from tholeiitic basalts show a much narrower range of ${ }^{\mathrm{IV}} \mathrm{Al}$. However, as a group, the tholeiitic basalt pyroxenes resemble cluster group $17-3$ as regards ${ }^{\text {IV }} \mathrm{Al}$.

Aluminum substitutes more extensively in tetrahedral than in octahedral sites in these pyroxenes. Figure 10 provides documentation for this statement in that the trend for ${ }^{\mathrm{IV}} \mathrm{Al}$ (as seen in Fig. 9) predominates even when combined with ${ }^{\mathrm{VI}} \mathrm{Al}$.

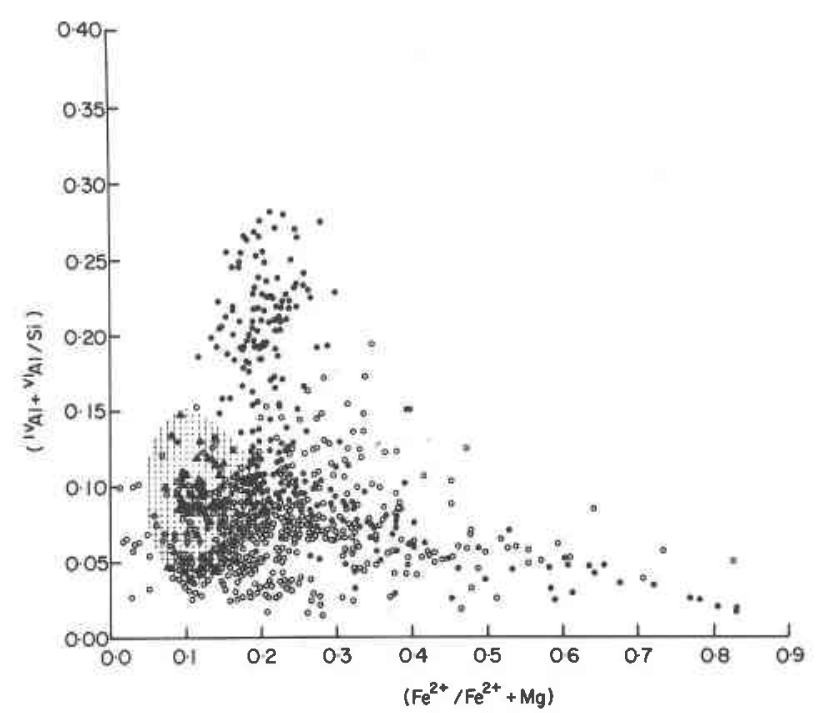

Fig. 10. $\left({ }^{\mathrm{V}} \mathrm{Al}+{ }^{\mathrm{VI}} \mathrm{Al}\right) / \mathrm{Si}$ vs. $\mathrm{Fe}^{2+} /\left(\mathrm{Fe}^{2+}+\mathrm{Mg}\right)$ (atomic). Symbols for groups and units are as in Fig. 3.

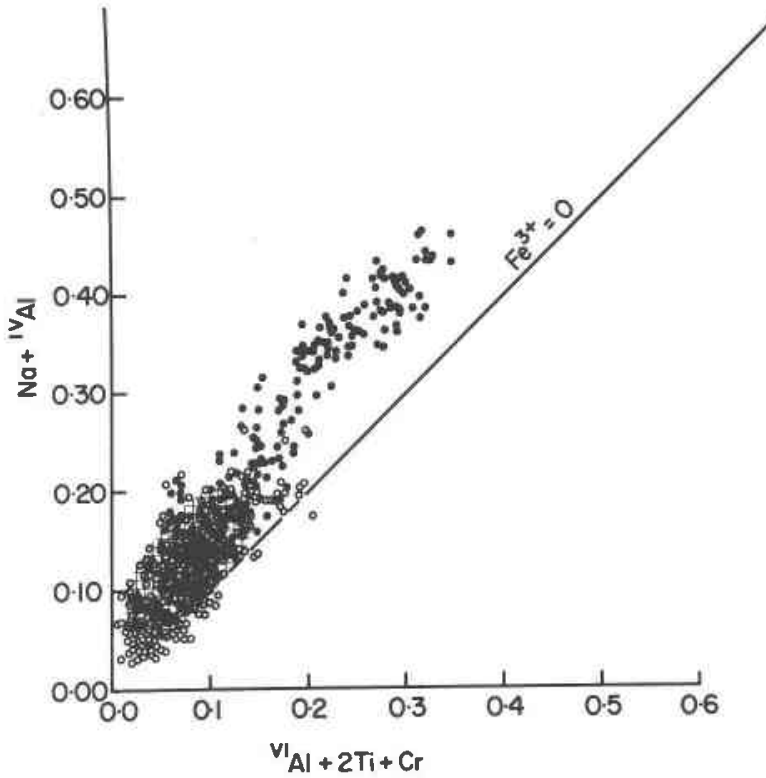

Fig. 11. Charge deficiencies ( $Y$ axis) vs. charge excesses ( $X$ axis). Symbols for groups and units are as in Fig. 3.

The ferric iron contents of the pyroxenes may be inferred from a plot (Fig. 11) of charge deficiencies $v s$. charge excesses. These charge imbalances are calculated relative to a pyroxene of charge-balanced composition, or "Quad" pyroxenes. For example, substitution of $\mathrm{Na}$ for $\mathrm{Ca}$ in the pyroxene $\mathrm{M} 2$ site or Al for Si in a tetrahedral site creates a charge deficiency relative to "Quad," whereas $\mathrm{Al}, \mathrm{Cr}^{3+}, \mathrm{Fe}^{3+}$, or $\mathrm{Ti}^{4+}$ in an octahedral site creates a charge excess. In Figure 11, lateral displacement of points to the left of the line $\mathrm{Fe}^{3+}=0$ indicates the relative amount of ferric iron present. The large number of analyses falling to the left of the $\mathrm{Fe}^{3+}=0$ line provides compelling evidence for significant ferric iron in these pyroxenes.

\section{Crystal-chemical characteristics}

The general formula for a pyroxene can be written $\mathrm{XYZ} \mathrm{O}_{2} \mathrm{O}_{6}$, where $\mathrm{X}$ represents $\mathrm{Ca}, \mathrm{Na}, \mathrm{Mn}^{2+}, \mathrm{Fe}^{2+}$, $\mathrm{Mg}$, and $\mathrm{Li}$ in the 6-8-coordinated $\mathrm{M} 2$ site; $\mathrm{Y}$ represents $\mathrm{Mn}^{2+}, \mathrm{Fe}^{2+}, \mathrm{Mg}, \mathrm{Fe}^{3+}, \mathrm{Cr}^{3+}, \mathrm{Al}$, and $\mathrm{Ti}^{4+}$ in the 6-coordinated $\mathrm{M} 1$ site; and $\mathrm{Z}$ represents $\mathrm{Si}$ and $\mathrm{Al}$ in the 4-coordinated $T$ site. Thus, the pyroxene structure accommodates most of the major cations that occur in basaltic systems. Papike et al. (1974) suggest a subdivision of pyroxenes into two major groups of structural chemical components which they call "Quad", and "Others." "Quad" pyroxene components are those which plot in the quadrilateral subsystem composed of the end-members diopside 
Table 4. Selected "Other-Other" correlations

\begin{tabular}{|c|c|c|c|c|c|c|c|c|}
\hline Cluster Group & ${ }^{\mathrm{V}} \mathrm{A} \mid-{ }^{\mathrm{IV}} \mathrm{Al}$ & ${ }^{{ }^{\mathrm{V}}} \mathrm{Fe}^{\mathrm{s+}+}{ }^{\mid{ }^{\mathrm{V}} \mathrm{Al}}$ & ${ }^{\mathrm{v}} \mathrm{Cr}^{3+}-{ }^{\mathrm{IV}} \mathrm{Al}$ & ${ }^{\mathrm{V}} \mathrm{Tij}^{4+}+{ }^{\mathrm{IV}} \mathrm{Al}$ & $\mathrm{Na}-{ }^{\mathrm{V} 1} \mathrm{Al}$ & $\mathrm{Na}-{ }^{{ }_{1}} \mathrm{Fe}^{3+}$ & $\mathrm{Na}-{ }^{\mathrm{V}} \mathrm{Cr}^{3+}$ & $\mathrm{Na}-{ }^{\mathrm{VI}} \mathrm{Ti}^{4+}$ \\
\hline $11-1$ & 0.446 & 0.489 & 0.148 & 0.574 & 0.168 & 0.235 & 0.168 & 0.286 \\
\hline $11-2$ & 0.578 & -0.026 & 0.043 & 0.753 & 0.409 & 0.046 & 0.081 & 0.223 \\
\hline 15 & 0.190 & 0.605 & 0.145 & 0.599 & 0.062 & 0.269 & -0.083 & 0.125 \\
\hline 17.1 & -0.318 & 0.601 & -0.086 & 0.822 & -0.135 & 0.287 & -0.307 & 0.268 \\
\hline $17-2$ & -0.406 & 0.339 & 0.095 & 0.935 & -0.011 & 0.069 & 0.196 & -0.042 \\
\hline $17-3$ & 0.687 & 0.234 & -0.161 & 0.677 & -0.078 & 0.010 & 0.150 & 0.328 \\
\hline $34-1$ & 0.057 & 0.404 & 0.279 & 0.505 & 0.117 & 0.053 & -0.015 & 0.380 \\
\hline $34-2$ & -0.311 & 0.869 & 0.458 & 0.886 & -0.119 & 0.625 & 0.604 & 0.733 \\
\hline $37-332$ & 0.369 & 0.635 & 0.245 & 0.571 & 0.227 & 0.222 & 0.239 & 0.259 \\
\hline Tholeiitic & 0.320 & 0.574 & 0.056 & 0.569 & -0.032 & 0.335 & -0.098 & 0.460 \\
\hline Alkalic & -0.041 & 0.718 & -0.185 & 0.965 & -0.051 & 0.642 & -0.218 & 0.302 \\
\hline
\end{tabular}

$\mathrm{CaMgSi}_{2} \mathrm{O}_{6}$, hedenbergite $\mathrm{CaFeSi}_{2} \mathrm{O}_{6}$, enstatite $\mathrm{MgSiO}_{3}$, and ferrosilite $\mathrm{FeSiO}_{3}$. Deviations from this reference state result in the "Other" pyroxene components. Pyroxene components in the "Others" group contain the cations $\mathrm{Al}, \mathrm{Fe}^{3+}, \mathrm{Cr}^{3+}, \mathrm{Ti}^{4+}$, and $\mathrm{Na}$. A site charge-balance equation indicates the 8 important coupled substitutions which are possible in the "Others" group:

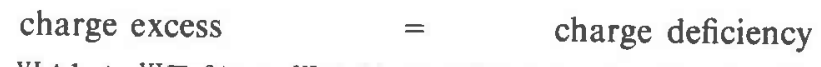

${ }^{\mathrm{VI}} \mathrm{Al}+{ }^{\mathrm{VI}} \mathrm{Fe}^{3+}+{ }^{\mathrm{VI}} \mathrm{Cr}^{3+}+2^{\mathrm{VI}} \mathrm{Ti}^{4+}={ }^{\mathrm{IV}} \mathrm{Al}+{ }^{\mathrm{M}}{ }^{2} \mathrm{Na}$

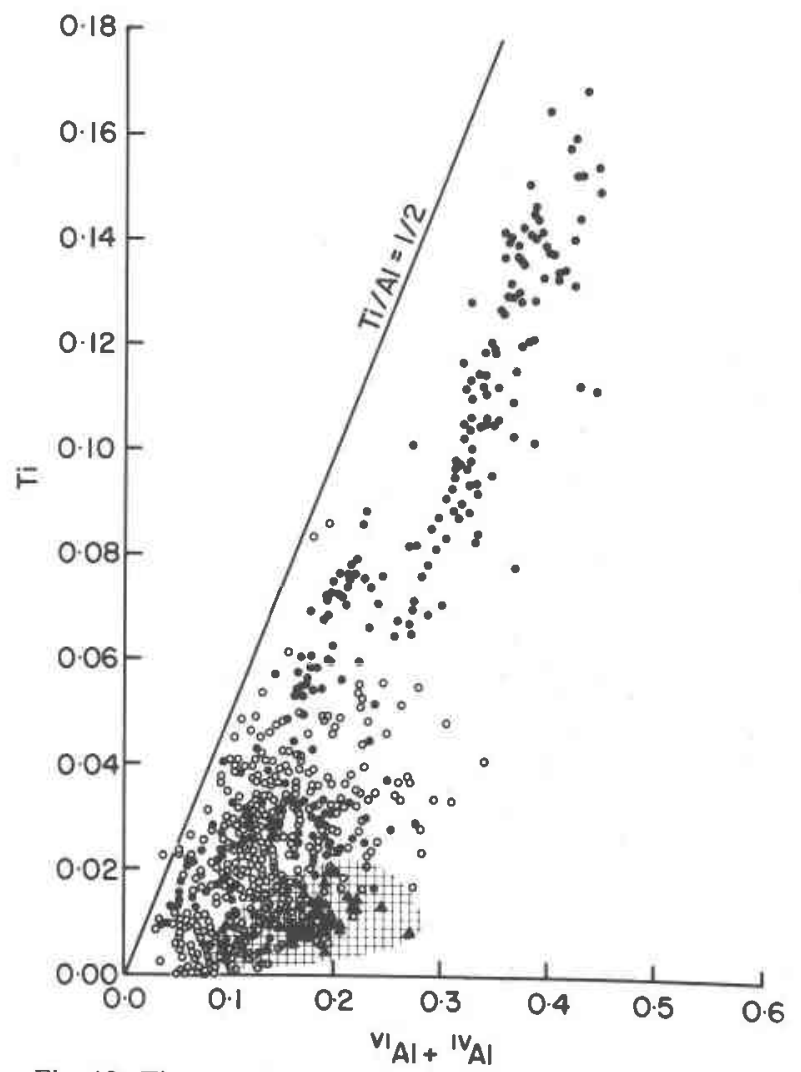

Fig. 12. Ti vs. total Al. Units are atoms per formula unit. See text for discussion.
When ${ }^{\mathrm{VI}} \mathrm{Al},{ }^{\mathrm{VI}} \mathrm{Fe}^{3+}$, or ${ }^{\mathrm{VI}} \mathrm{Cr}^{3+}$ substitutes in the pyroxene M1 site, a charge excess of +1 results relative to the $\left(\mathrm{Mg}, \mathrm{Fe}^{2+}\right)$ occupancy of this site in "Quad" pyroxene components. By similar reasoning, a $\mathrm{Ti}^{4+}$ substitution in Ml causes a charge excess of +2 relative to "Quad." Obviously, for charge balance to be maintained in the pyroxene structure, these site charge excesses must be counterbalanced by site charge deficiencies. The substitution of $\mathrm{Al}$ for $\mathrm{Si}$ in the tetrahedral site causes a deficiency of -1 . Similarly, the substitution of $\mathrm{Na}$ in the $\mathrm{M} 2$ site for $\left(\mathrm{Ca}, \mathrm{Fe}^{2+}, \mathrm{Mg}\right)$ also results in a site charge deficiency of -1 relative to "Quad." Although the classification of pyroxenes suggested by Papike et al. was specifically designed to minimize any arbitrary sequential calculation of components, our new results from factor analysis of pyroxenes from deep-sea basalts enables us to identify relative importance of the different components and thus gives us a basis for a calculation sequence.

Correlation coefficients have been calculated from the correlation matrices of the factor analyses for every pair of cations studied. For simplicity, the correlations are separated into two groups. Table 4 presents the "Other-Other" cation correlations which correspond to the eight important coupled "Other" substitutions mentioned above. Table 5 presents the "Other-Quad" correlations. Silicon is not included, since it is redundant with ${ }^{\mathrm{IV}} \mathrm{Al}\left({ }^{\mathrm{IV}} \mathrm{Al}=2-\mathrm{Si}\right)$.

Among the "Other-Other" pairs, Ti- ${ }^{\mathrm{IV}} \mathrm{Al}$ and $\mathrm{Fe}^{3+}$ $-{ }^{\mathrm{IV}} \mathrm{Al}$ are among the most strongly correlated, indicating that ${ }^{\mathrm{VI}} \mathrm{Ti}^{4+}-2^{\mathrm{IV}} \mathrm{Al}$ and ${ }^{\mathrm{VI}} \mathrm{Fe}^{3+}-{ }^{\mathrm{IV}} \mathrm{Al}$ are the two most important "Others" substitutional couples in pyroxenes from deep-sea basalts. They are of roughly equal importance in pyroxenes from tholeiitic basalts, but in pyroxenes from alkalic basalts ${ }^{\mathrm{VI}} \mathrm{Ti}^{{ }^{4+}}-2^{\mathrm{IV}} \mathrm{Al}$ is more important. Thus, important site substitutions are $\mathrm{Ti}^{4+}$ or $\mathrm{Fe}^{3+}$ for $\left(\mathrm{Mg}, \mathrm{Fe}^{2+}\right)$ in the $\mathrm{M} 1$ site, coupled with $\mathrm{Al}$ for $\mathrm{Si}$ in the tetrahedral site. 
Table 4 summarizes important information concerning the most important "Others" substitutional couples. In pyroxenes from tholeiitic basalts the most to least important are: ${ }^{\mathrm{VI}} \mathrm{Fe}^{\mathrm{s+}}{ }^{\mathrm{IV}} \mathrm{Al},{ }^{\mathrm{VI}} \mathrm{Ti}^{4+}+{ }^{\mathrm{IV}} \mathrm{Al}, \mathrm{Na}-$ ${ }^{\mathrm{V}} \mathrm{Ti}^{4+}, \mathrm{Na}-{ }^{\mathrm{VI}} \mathrm{Fe}^{3+},{ }^{\mathrm{VI}} \mathrm{Al}-{ }^{\mathrm{IV}} \mathrm{Al}$. In pyroxenes from alkalic basalts the sequence is: ${ }^{\mathrm{VI}} \mathrm{Ti}^{4+}{ }^{\mathrm{IV}} \mathrm{Al},{ }^{\mathrm{V}} \mathrm{Fe}^{3+}$ ${ }^{\mathrm{IV}} \mathrm{Al}, \mathrm{Na}{ }^{{ }^{\mathrm{V}}} \mathrm{Fe}^{3+}, \mathrm{Na}^{\mathrm{VI}} \mathrm{Ti}^{4+}$. Additional correlation coefficients (not shown) and the results presented in Table 4 indicate that $\mathrm{NaTi}(\mathrm{SiAl}) \mathrm{O}_{\theta}$ is a significant component in pyroxenes from both tholeiitic and alkalic basalts. The substitutional couples $\mathrm{Na}^{\mathrm{VI}} \mathrm{Cr}^{3+}$ (ureyite) and $\mathrm{Na}^{\mathrm{VI}} \mathrm{Al}$ (jadeite) are not important in pyroxenes from either group. However, ${ }^{\mathrm{VI}} \mathrm{Al}-{ }^{\mathrm{IV}} \mathrm{Al}$ is a significant substitution in pyroxenes from tholeiitic basalts but is insignificant for pyroxenes from alkalic basalts. The high positive correlation between Ti and Al (especially for alkalic pyroxenes, correlation coefficient $=0.965$ ) is illustrated in Figure 12.

Table 5 enables us to see if these substitutional couples correlate preferentially with any of the "Quad" cations $\left(\mathrm{Ca}, \mathrm{Fe}^{2+}, \mathrm{Mg}\right)$. In pyroxenes from tholeiitic basalts $\mathrm{Ti}$ is positively correlated with $\mathrm{Fe}^{2+}$ and negatively correlated with $\mathrm{Mg}$; this indicates a $\mathrm{Ti}$ buildup in the pyroxenes with fractionation. Thus, in these pyroxenes the ${ }^{\mathrm{V} 1} \mathrm{Ti}^{4+}-2^{\mathrm{IV}} \mathrm{Al}$ couple is more important in late-stage pyroxenes. In contrast, since $\mathrm{Ti}$ is negatively correlated with $\mathrm{Fe}^{2+}$ in the pyroxenes from alkalic basalts, the ${ }^{\mathrm{VI}} \mathrm{Ti}^{4+}-2^{1 \mathrm{v}} \mathrm{Al}$ couple is more important in the early-crystallizing pyroxenes from alkalic basalts and falls off with fractionation.

Figure 13 gives additional important insights into pyroxene chemical systematics for the three major groups, alkalic, tholeiitic, and site 100. Pyroxenes from alkalic basalts plot along a line connecting ${ }^{\mathrm{VI}} \mathrm{Ti}$ ${ }^{I V} \mathrm{Al}_{2}$ and ${ }^{\mathrm{VI}} \mathrm{Fe}^{3+\mathrm{IV}} \mathrm{Al}$, which are the two most important "Others" substitutional couples. In early-crystallizing pyroxenes from these basalts ${ }^{\mathrm{VI}} \mathrm{Ti}^{\mathrm{IV}} \mathrm{Al}_{2}$ is the dominant couple, but in late-stage pyroxenes ${ }^{\mathrm{VI}} \mathrm{Fe}^{\mathrm{s}+}$ ${ }^{\mathrm{IV}} \mathrm{Al}$ dominates. Pyroxenes from tholeiitic basalts plot off the $\mathrm{TiAl}_{2}-\mathrm{Fe}^{3+} \mathrm{Al}$ line toward the ${ }^{\mathrm{IV}} \mathrm{Al}$ apex of the data display. This reflects the additional important "Others" couples in these pyroxenes, namely, $\mathrm{Cr}^{3+} \mathrm{Al}$ (especially for Site 100 ) and ${ }^{\mathrm{VI}} \mathrm{Al}{ }^{\mathrm{IV}} \mathrm{Al}$. Thus, for Site 100 pyroxenes the crystallization trend would be initiated at the $\mathrm{Ti}-{ }^{\mathrm{IV}} \mathrm{Al}$ sideline near ${ }^{\mathrm{IV}} \mathrm{Al}$. These pyroxenes would be enriched in the $\mathrm{Cr}^{3+} \mathrm{Al}$ and ${ }^{\mathrm{VI}} \mathrm{Al}$ ${ }^{\mathrm{IV}} \mathrm{A} 1$ components. With increased crystallization the trend is toward ${ }^{\mathrm{VI}} \mathrm{Fe}^{3+\mathrm{IV}} \mathrm{Al}$.

Factor analysis, correlation coefficients, and sequential calculations of pyroxene components

Papike et al. (1974) introduced a method for characterizing pyroxenes that specifically avoided any ar-

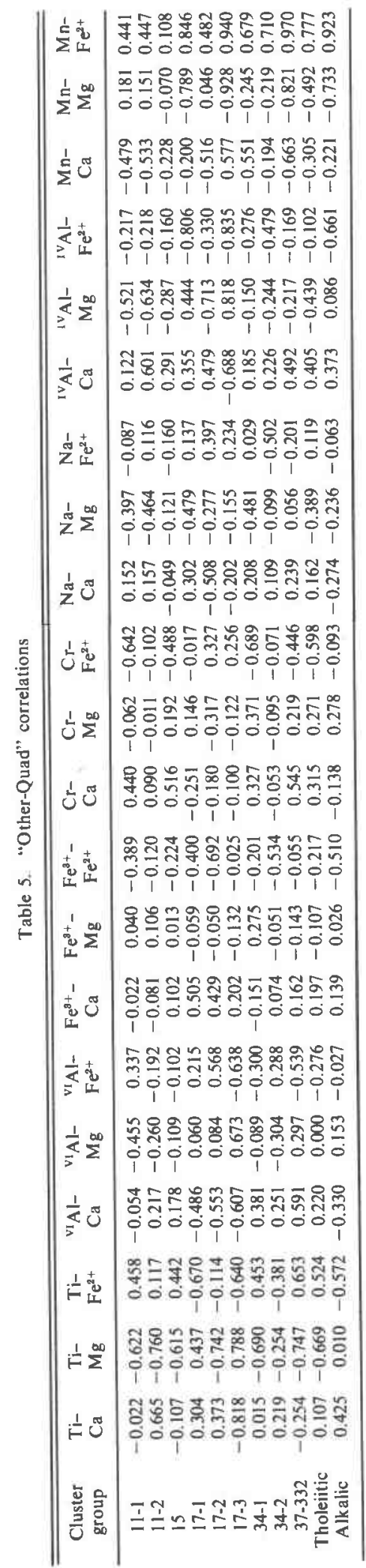




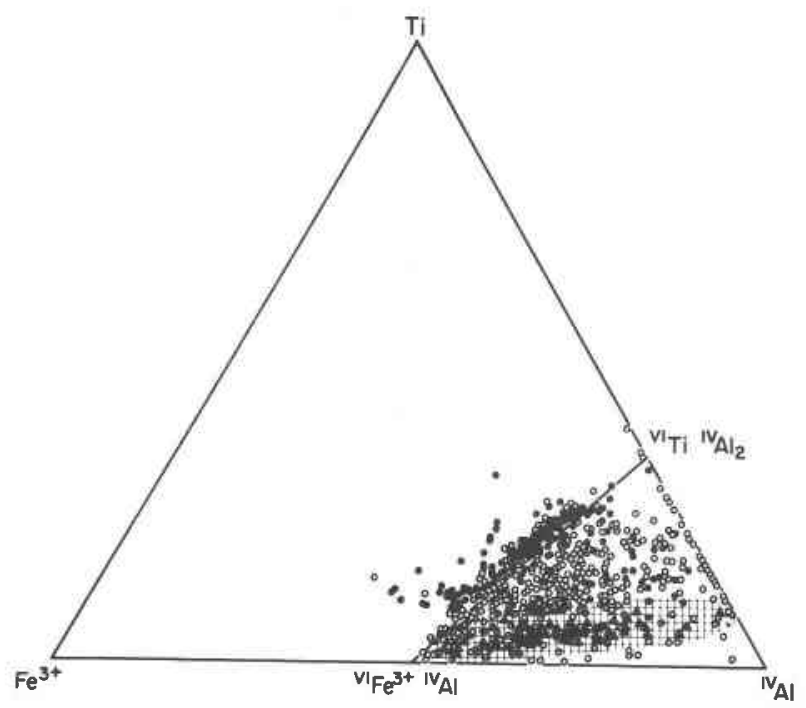

Fig. 13. Ti-Fe $\mathrm{Fe}^{3+}{ }^{\mathrm{IV}} \mathrm{Al}$ (atomic) data display. Symbols as in Fig. 3.

bitrary sequential calculation of pyroxene components. By using the methods of factor analysis and cation-cation correlation coefficients we may return to sequential calculation of pyroxene components.

For an example of a calculation of the pyroxene components, we refer to Tables 2, 4, and 5 and will apply the calculation specifically to pyroxene cluster group 17-2. The correlation coefficients presented in Tables 4 and 5 indicate that $\mathrm{CaTiAl}_{2} \mathrm{O}_{6}$ is the most important "Others" component followed by $\mathrm{CaFe}^{3+}$ $\mathrm{SiAlO}_{6}$. By sequentially calculating these components the pyroxene can be characterized as 12 percent $\mathrm{CaTiAl}{ }_{2} \mathrm{O}_{6}, 11$ percent $\mathrm{CaFe}^{3+} \mathrm{SiAlO}_{6}$ and 77 percent Quad. By normalizing $\mathrm{Ca}, \mathrm{Fe}^{2+}+\mathrm{Mn}$, and $\mathrm{Mg}$ (the Quad components) to 100 percent we can calculate the Wo, En, and Fs proportions of Quad as 43.1, 12.5 , and 44.4 percent, respectively.

Figure 14 illustrates the pyroxene data plotted on a $\mathrm{Ca}-\mathrm{Mg}-\mathrm{Fe}^{2+}$ ternary. Cluster group 17-2 (Fig. 14b) plots in a somewhat curious position on this plot above the join $\mathrm{CaMg}-\mathrm{CaFe}^{2+}$. At first glance one might assume that this implies that some $\mathrm{Ca}$ is entering the pyroxene M1 site, but this is not the case. The correlation coefficients indicate that $\mathrm{Ca}$ is highly correlated with ${ }^{\mathrm{V}} \mathrm{Ti}$ and ${ }^{\mathrm{VI}} \mathrm{Fe}^{3+}$ and thus some of it should be included with the "Others," not the "Quad" components. When one makes this adjustment as illustrated in the calculation above, we see that cluster group 17-2 plots properly within the pyroxene quadrilateral.

Based on the results of this study the correct sequential calculation for pyroxenes from alkalic ba- salts is $\mathrm{CaTiAl}_{2} \mathrm{O}_{6}, \mathrm{Ca}^{\mathrm{vI}} \mathrm{Fe}^{3+} \mathrm{SiAlO}_{6}, \mathrm{NaFe}^{3+} \mathrm{Si}_{2} \mathrm{O}_{6}$, $\mathrm{NaTi}^{4+} \mathrm{SiAlO}_{6}$. In contrast the correct sequential calculation for pyroxenes from tholeiitic basalts is $\mathrm{CaFe}^{3+} \mathrm{SiAlO}_{6}, \mathrm{Fe}^{2+} \mathrm{TiAl}_{2} \mathrm{O}_{6}, \mathrm{NaTiSiAlO}_{6}, \mathrm{NaFe}^{3+}$ $\mathrm{Si}_{2} \mathrm{O}_{6}, \mathrm{Ca}^{\mathrm{VI}} \mathrm{AlSi}^{\mathrm{IV}} \mathrm{AlO}_{6}, \mathrm{Mg}^{\mathrm{VI}} \mathrm{Cr}^{3+} \mathrm{SiAlO}_{6}$.

\section{Conclusions}

Differences in pyroxene chemistry reflect chemical differences in the types of basalt in which they occur. Pyroxenes from alkalic and tholeiitic rocks differ primarily in the abundances of the components $\mathrm{Cr}_{2} \mathrm{O}_{3}$, $\mathrm{TiO}_{2}$, and $\mathrm{Na}_{2} \mathrm{O}$. With increased fractionation [as measured by an increase in $\mathrm{Fe}^{2+} /\left(\mathrm{Fe}^{2+}+\mathrm{Mg}\right)$ ratio] several trends in these components are observed. Thus, in the pyroxenes from tholeiitic rocks there is an inverse relation between fractionation and $\mathrm{Cr}$ con-

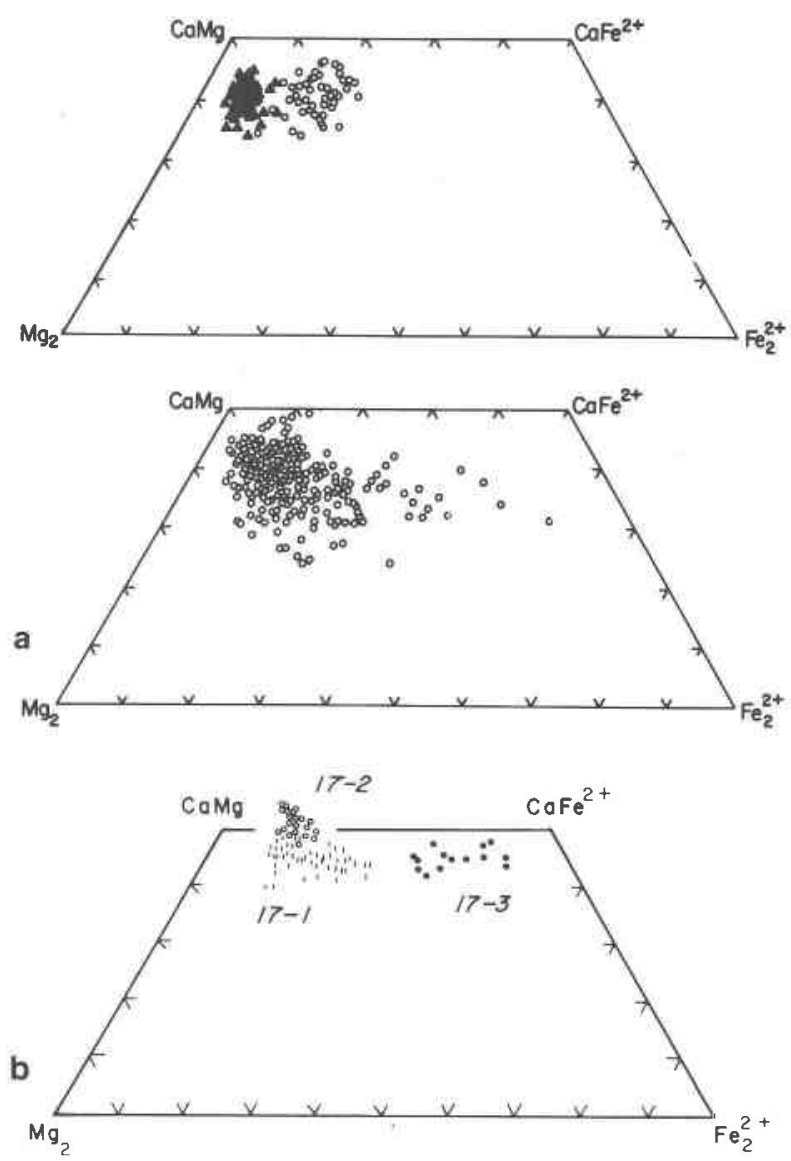

Fig. 14. (a) Pyroxene data for tholeiitic basalts plotted on $\mathrm{Ca}-$ $\mathrm{Mg}-\mathrm{Fe}^{2+}$ (atomic) ternary diagrams. The upper diagram is for pyroxenes from Leg 11. Triangles represent cluster group 11-1 and open circles 11-2. The lower diagram illustrates combined data for cluster groups 15, 34-1, 34-2, 37-332. (b) Pyroxene data for alkalic basalts plotted on a $\mathrm{Ca}-\mathrm{Mg}-\mathrm{Fe}^{2+}$ (atomic) ternary diagram. Three cluster groups are indicated. 
tent. In pyroxenes from alkalic rocks $\mathrm{Ti}$ content is inversely related to fractionation.

Using correlation coefficients and crystal-chemical reasoning, we infer from our data that substitutions which commonly occur in these deep-sea pyroxenes are: $\mathrm{Al}$ for $\mathrm{Si}$ in the tetrahedral site, balanced by either $\mathrm{Ti}$ or $\mathrm{Fe}^{3+}$ for $\mathrm{Fe}^{2+}$ or $\mathrm{Mg}$ in an octahedral $\mathrm{M} 1$ site.

Fresh pyroxenes, even in highly altered basalts, provide clues about the original chemical character of their host rocks.

\section{Acknowledgments}

$\mathrm{K}$. Baldwin is acknowledged for his advice on the use of the computer programs. Thorough reviews by M. Bass, E. Dowty, and $F$. Chayes markedly improved the manuscript. This research was supported by NSF grant OCE7622193A01 (AEB) and NASA NSG-9044 (JJP), which we gratefully acknowledge.

\section{References}

Ayuso, R. A., A. E. Bence and S. R. Taylor (1976) Upper Jurassic tholeiitic basalts from DSDP Leg 11. J. Geophys. Res., 81, 43054335.

Bass, M. N., R. Moberly, J. M. Rhodes, C. Shih and S. E. Church (1973) Volcanic rocks cored in the Central Pacific, Leg 17, Deep Sea Drilling Project. Initial Rep. Deep Sea Drilling Project, 17, 429-503.

Bence, A. E. and A. L. Albee (1968) Empirical correction factors for electron microanalysis of silicates and oxides. J. Geol., 76, 382-403.

- and J. J. Papike (1972) Pyroxenes as recorders of lunar basalt petrogenesis: Chemical trends due to crystal-liquid interactions. Proc. Lunar Sci. Conf. 3rd, 431-469.

— — - and R. A. Ayuso (1975) Petrology of submarine basalts from the Central Caribbean: DSDP Leg 15. J. Geophys. Res., 80, 4775-4804.

Bender, J. F., F. N. Hodges and A. E. Bence (1978) Petrogenesis of basalts from the Project FAMous area: experimental study from 1 atm. to $15 \mathrm{~kb}$. Earth Planet. Sci. Lett., 41, 277-302.

Blanchard, D. P., J. M. Rhodes, M. A. Dungan, K. V. Rodgers, C. M. Donaldson, J. C. Brannon, J. W. Jacobs and E. K. Gibson (1976) The chemistry and petrology of basalts from Leg 37 of the Deep Sea Drilling Project. J. Geophys. Res., 81, 4231-4246.
Christofersson, E. (1976) Colombian Basin magnetism and Caribbean plate tectonics. Geol. Soc. Am. Bull., 87, 1255-1258.

Dixon, W. J., Ed. (1975) BMDP Biomedical Computer Programs. University of California Press, Berkeley, California.

Dmitriev, L. (1977) Petrochemistry of basalts and plutonic rocks, Leg 37, Deep Sea Drilling Project. Initial Rep. Deep Sea Drilling Project, 37, 681-693.

Donnelly, T. W. (1973) Late Cretaceous basalts from the Caribbean: a possible flood basalt of vast size (abstr.). EOS, Trans. Am. Geophys. Union, 54, 1004-1006.

Edgar, N. T., J. B. Saunders et al. (1973) Initial Reports of the Deep Sea Drilling Project, vol. 15. U. S. Government Printing Office, Washington, D. C.

Grove, T. L. and A. E. Bence (1977) Experimental study of pyroxene-liquid interaction in quartz-normative basalt 15597. Proc. Lunar Sci. Conf. 8th, 1549-1579.

Hodges, F. N. and J. J. Papike (1977) Petrology of basalts, gabbros, and peridotites from DSDP Leg 37. Initial Rep. Deep Sea Drilling Project, 37, 711-723.

Hollister, C. D., J. I. Ewing, et al. (1972) Initial Reports of the Deep Sea Drilling Project, vol. 11. U. S. Government Printing Office, Washington, D. C.

Kushiro, I. (1973) Origin of some magmas in oceanic and circumoceanic regions. Tectonophysics, 17, 211-222.

Mazzullo, L. J. and A. E. Bence (1976) Abyssal tholeiites from DSDP Leg 34: the Nazca Plate. J. Geophys. Res., 81, 4327-4351.

Myers, C. W., A. E. Bence, J. J. Papike and R. A. Ayuso (1975) Petrology of an alkali-olivine basalt sill from Site 169 of DSDP Leg 17: the Central Pacific Basin. J. Geophys. Res., 80, 807-822.

Naney, M. T., D. M. Crowl and J. J. Papike (1976) The Apollo 16 drill core: Statistical analysis of glass chemistry and the characterization of a $H$ igh Alumina-Silica Poor (HASP) glass. Proc. Lunar Sci. Conf., 7, 155-184.

Papike, J. J., K. L. Cameron and K. Baldwin (1974) Amphiboles and pyroxenes: characterization of other than quadrilateral components and estimates of ferric iron from microprobe data (abstr.). Geol. Soc. Am. Abstracts with Programs, 6, 1053-1054.

Schweitzer, E. L., J. J. Papike and A. E. Bence (1978) Clinopyroxenes from deep sea basalts: a statistical analysis. Geophys. Res. Lett., 5, 573-576.

Yeats, R. S., S. R. Hart et al. (1976) Initial Reports of the Deep Sea Drilling Project, vol. 34. U. S. Government Printing Office, Washington, D. C.

Manuscript received, July 3, 1978; accepted for publication, December 9, 1978. 